\title{
The Sun and Satellite: A Study of Gender Relations in Television Advertisements and its Relationship to the Position of Women in Indian Households
}

Chetna Bhatia ${ }^{1 *}$ and Madhu Deep Singh ${ }^{2 *}$

${ }^{1}$ VIPS, GGIPSU,India

'IMC\&MT, Kurukshetra University, India

\begin{abstract}
While the contemporary Indian feminists are busy in on-street protests and campaigns regarding woman's mobility, what is going on inside the Indian households assumes more importance due to its major role in shaping the attitudes and outlook of men and women participating in such events. Advertisements, in a globalized India, act as a major platform for selling the products of MNC's. The brain surgeons sitting in ad agencies position various products by targeting Indian families and portraying images of their values, patterns of relationship and space shared by the members. And television being a living room mass medium with high reach multiplies its scope of touching different aspects of personal and public life of the families. Gender relations are one of them. Previous studies in this field have been confined to sex roles, stereotypes and portrayal of women as a mother, wife and working lady in the ads. This paper attempts to study the patterns of gender relations portrayed in television advertisements and its relationship to the current positon of women in Indian households. The study is undertaken with broader reference to the division of labor, decision-making, help, advice, mobility and interpersonal communication between male and female partners in the family.

Method of content analysis, both quantitative and qualitative, was used to analyze 500 Hindi television advertisements using codes based on these four parameters. For the second part, a survey was conducted from 500 respondents in the metropolitan capital city of Delhi. The questionnaire listed various tasks and decisions of routine family life on a nominal scale. Another Section contained attitudinal statements about women with reference to various roles and decisions involved in domestic, financial and outdoor situations between husband and wife. The agreement of respondents was measured using 5-point Likert Scale. It was found that the position of Indian women in the capital city is like a satellite which depends on the Sun to receive light. And the same pattern is reflected in television advertisements. It was concluded that with the motive of increasing their sales, advertisers are trying to encourage anti-feminist mindset by portraying male dominance in both public and private spaces of the society.
\end{abstract}

Keywords: Relations; Mass communication; Advertisements; Television; Consumer

\section{Introduction}

Advertising, by its very nature, is commercial. Its primary aim is to sell products and services and get maximum profit through it. According to CA Krickpatrick, "Advertising is a mass communication of information intended to persuade buyers so as to maximize their profit."(pp.18) The ever increasing competition between companies, especially after privatization and liberalization, makes a consumer cluttered with advertisements all around every time- on roads, trains, buses, walls, polybags, book covers, television, pamphlets, radio, newspaper and many other places. This genre works through images still or moving or both to catch attention of the customer, create his/her interest towards knowing about the products followed by a desire to get it, to convincing to buy it and bring him to the store for the required action. Lakhs of crores are spent on this persuasive mass communication exercise. So, to make it effective and result-oriented,,the advertiser relies on its marketing research department that conducts consumer research to understand and measure the behavior, needs and wants of the prospective consumer as an individual and as part of a group. This department studies and categorizes the social, psychological and economic background of various groups in the society, their likes and dislikes. It then tries to match the products and services of the firm with these traits- needs, moods, tastes, financial prowess, prestige of the targeted market segment to make the message more acceptable and get the audience connected to the images shown in the ads. Major factors that are incorporated in the advertising message include the culture and society of the audience along with the family. While the former includes tangible items (arts, literature, buildings, furniture, clothing and music) and intangible items (history, knowledge, laws, morals and customs) that define lifestyle of a group, the later acts as an important reference group. That is, family is a group of people that the consumers use as a guide for behaving in specific situations. Since advertisements show men and women in different forms and roles, their images present a relationship between both the genders, That is, it shows who dominates the other inside the home, outside and at workplace as well. Thus, in addition to informing about products and services, advertising constructs a secondary discourse about society and power relations. Gender relations are one of them. These meanings are constructed, mediated and when repeated over time, these are internalized by various members of society. So, the various codes used in ads in the presentation of women have a direct bearing on the nature of relationship that exists between both the genders in society.

*Corresponding author: Singh MD, Assistant Professor, IMC\&MT, Kurukshetra University, Kurukshetra, India, Bhatia C, Assistant Professor, VIPS, GGIPSU, New Delhi, India, Tel: 0751 - 2496025; E-mail: madhu.deep04@gmail.com; chetna.whatsnew@gmail.com

Received December 15, 2016; Accepted December 19, 2016; Published December 23, 2016

Citation: Bhatia C, Singh MD (2016) The Sun and Satellite: A Study of Gender Relations in Television Advertisements and its Relationship to the Position of Women in Indian Households. J Mass Communicat Journalism 6: 324. doi: 10.4172/2165-7912.1000324

Copyright: @ 2016 Bhatia C, et al. This is an open-access article distributed under the terms of the Creative Commons Attribution License, which permits unrestricted use, distribution, and reproduction in any medium, provided the original author and source are credited. 
Bina Aggarwal in 'A Field of One's Own' defines gender relations as " the relations of power between women and men which are revealed in a range of practices, ideas, representations, including the division of labor, roles and resources between women and men and the ascribing to them of different abilities, attitudes, desires, personality traits, behavioral patterns and so on [1]. Gender relations are both constituted by and help constitute these practices and ideologies in interaction with other structures of social hierarchy such as class, caste and race. They may be seen as largely socially constructed (rather than biologically determined) and as variable over time and place" (pp.51). From the beginning of history, the sexual division of labor in the early civilization was manual. Men used to work outside whereas women remained at homes. Men were usually involved in the tasks related to security, protection, earning food for the family like hunting etc., which made them involved more in social life of the community. Whereas women were involved in domestic activities like cooking, child rearing, nursing etc. In this way, women were thought suitable for reproduction and got associated with motherhood. Whereas men were associated with hard physical work, decision making and dealing with matters outside the family. This made men, as a group, more powerful than women that resulted in subordination and oppression of women. Thus, in this manner, power got associated with "being male" whereas softness, tenderness and sensitivity with "being female". This association of certain characteristics with the sex of human beings has its philosophical reasoning in the "Biological Determinism" theory of feminism that legitimizes various forms of oppression as natural and inescapable, because the oppression arises supposedly from natural and therefore unchangeable factors. Initially, the term 'sex' was used to refer to the biological differences between men and women whereas 'gender' indicated the vast range of cultural meanings attached to that basic difference. Like caste system, this two-sex model/ sex based polarization of society is based on the assumption that certain groups of people (here men) are superior by birth, and that they are born with intelligence and special skills that justify their power in society [2].

Thus, feminists have argued that there is no co-relation between the biology of men and women and the qualities that are thought to be masculine and feminine, rather it is the child-rearing practice in a society that trains boys and girls appropriate gender-specific behavior, play, dress and so on. Therefore, on one hand, women are supposed to be physically weak for heavy manual labor, but both in the home and outside, they do the heaviest of work- carrying heavy loads of water, firewood, grinding corn, transplanting paddy, carrying head loads in mining and construction work. As Simone de Beauvoir puts it, "One is not born, but rather becomes, a woman" (pp.301) [3]. In addition, societies generally value "masculine" characteristics more highly than "feminine" ones. This sexual division of labor extends even to the "public" arena of paid work. More important fact is that whatever work that women do, gets lower wages and is less valued. For example, nursing and teaching (particularly at low levels) are predominantly female professions and are comparatively ill-paid than other white collar jobs that the middle classes take up.

As Foucault analyzed in his genealogies of power/knowledge that analysis of power relations is central to understanding the nature and causes of women's subordination [4]. The traditional model of power as repression traces the oppression of women onto the patriarchal social structures which secure the power of men over women. Sylvia Walby in "Theorizing Patriarchy" calls it "a system of social structures and practices in which men dominate, oppress and exploit women"(pp.20) [5].These power relations are hierarchical and unequal where men control women's production, reproduction and sexuality.
Talking on family structure in 'The German Ideology', Marx and Engels insisted on interrelationship between the history of humankind and the history of industry and exchange [6]. They term 'family' as the first social relationship in sense of co-operation of individuals in producing other humans, which is further subordinated in society for new needs arousing due to new members. Putting their view further, they find the similarity between producing daily material life (earning) and producing other humans as in the former case, industry controls the labor, in the later men exercise their control over women's labor, their reproductive power- control over body and sexualities. They term it relationship of pleasure and work, of powerful and weak, of domination and subordination, of consumption and production. Thus, this organization called family becomes a subordinated relationship. Liberal feminists hold mass media responsible for promoting sexism by training individuals to confirm to gender-specific behavior in society. They argue that mass media acts as an agent of socialization by promoting the attitude that separate public (for men) and private (for women) spheres should exist. And this makes them ignore or trivialize women in media and their symbolic annihilation continues till date. This creates gender inequality.

\section{Present Study}

As discussed above, socialization acts as a major factor in developing the meanings of being 'male' and 'female' in any society and mass media, as mentioned above, acts as one of the agents of this process. Advertising, being a commercial form of mass communication, portrays different images of males and females with an objective of selling the products and services. Such kind of portrayal conveys some meanings regarding the nature of relationship that exists between both the genders which is further related to the values, patterns of relationship and space shared by the members in a family. When done through a high reach living room mass medium like television, its scope of touching personal and public life of families gets multiplied. The current study attempts to look at the way in which gender relations as portrayed in television advertisements are related to those existing in the society. Considering such kind of relationship as the one that contains exertion of power by one member over the other, these would be observed in the form of position that women hold in the family and society in terms of her roles, nature of involvement in various decisions and the pattern in which tasks are divided amongst both the genders. That is, the behavior, expectations and treatment given to women by males and other members of society associated with them would be measured.

Since the previous studies done in this field have been limited to either analyzing the content or measuring the opinion of society, this paper goes a step ahead of them by actually relating both of these. This would yield a rich data about the current mindset of Indian society which has traditionally been described as patriarchal by feminist scholars like Radha Kumar, Kamla Bhasin, Nivedita Menon and many others $[7,8]$. In fact, it would reveal the mindset of those living in the capital city of Delhi- the one that gets maximum exposure to multinational companies as hubs of globalization and privatization. Moreover, $70 \%$ of the parameters used in this paper are made by the authors themselves, thus leading to the addition of some more parameters in the field of gender-related analysis of the content of television advertisements. The findings and conclusion of the study has the scope of giving a glimpse of the way television advertisements are functioning in context of the Indian society.

\section{Review of Literature}

Initial studies in this field undertaken by Silverstein and 
Silverstein, JS Yadav and Abhilasha Mohnot, Abhik Roy focused on sex roles and stereotyped images of housewives and working women in advertisements [9-11]. While some international studies undertaken by Young Sook Moon and Kara Chan, Atif Nassif and Barrie Gunter, Elza Ibroscheva focused on cross-cultural comparison in terms of women's portrayal in advertisements, a pioneer study by Erving Goffman put forward the ways of judging superior-inferior position of women in still advertisements [12-15]. Going a step ahead of content analysis, William J Lundstrom, Donald Sciglimpaglia conducted a survey of 800 respondents that measured the attitude of viewers towards the image of the company portraying women in its advertisement, objectification of women and attitude towards buying products from that company in future. In their work titled 'Sex Role Portrayals in Advertising', they used the 'Advertising Opinion Survey' Scale [16]. The t-test found that more women than men were critical of the image of women as presented in the advertisements. Among women, more educated, high class, younger and liberal ones were more critical in their views. While the males were not critical of the company image, both were against sexual objectification. Both the sexes had no problem in buying products from those companies in future. Focusing only on the females, Donald Sciglimpaglia, William J Lundstrom, Dinoo J Vanier conducted a three-fold analysis and studied their attitude towards advertising, sex role stereotypes and feminine role orientation [17]. The respondents felt that advertising is a good source of information. The scholars categorized the respondents either as 'Modern' or 'Traditional' through a survey based on the Arnott Scale of Feminine Role Orientation. Both the groups were exposed to television advertisements portraying women. The respondents felt that both male and female characters were inaccurately portrayed. It was also observed that 'Modern' women more critical towards the portrayal than the 'Traditional' ones. The study stressed on the need of more realistic portrayal. An excellent critical analysis of ads was done by Ali Haji Mohammadi from Iran. In his study titled 'A critical analysis of women's representation in TV advertisements from a cultural studies perspective', he found out that the ads highlighted the social dominant discourse (patriarchal) and marginalized the other discourse (feminine) [18]. Hence, they shape attitudes to male and female genres so that the power of this discourse becomes naturalized according to common sense. Thus, it serves the naturalization of the dominant discourse's belief that is patriarchal. In these advertisements, agenda setting and marginalization are ways for maintaining and continuing power within discourses. Using another method of qualitative analysis, T Sangaris and E Nina-Pazarzi from University of Piraeus, Greece examined the construction of Women's Image in Greek TV Commercials [19]. The semiotic analysis of Ads proved the hypothesis that the construction of specific representations reflected the existing power relations characterizing patriarchal societies, which in turn influenced the attitudes of advertising networks. Among the studies focusing on the attitude of society towards woman, the one conducted by Catherine I. Bolzendahi (Indiana University), Daniel J Myers (university of Notre Dame) in 2004 explored the factors responsible for such opinion [20]. The study titled 'Feminist Attitudes and Support for Gender Equality: Opinion change in Women and Men, 1974-1998' compared the attitudes from two different time periods. The survey found that the important determinants are those related to employment, reflecting family structures and their background and socialization indicators. Further, it was concluded that the attitudes continued to liberalize and converge with the 'abortion' as exception. Predictors were similar for both men and women. Two reports by UNESCO set benchmarks for researchers. The first report 'Mass Media: The Image, role and Social Conditions of Women', Furnham and Mak conducted meta-analysis of fourteen studies in eleven countries on five continents over 25 years from 1975 to 1999 on gender role stereotyping in television commercials, and the second report 'Content Discontent - Towards a Fair Portrayal of Women in Media edited by Diana Burns analyzed the language of commercials in terms of being 'sexist' or 'nonsexist' [21-23]. A deep investigation and discussion of various aspects of Gender relations in India has been discussed by Tim Dyson, Mick Moore in their work 'On Kinship Structure, Female Autonomy, and Demographic behavior in India' [24]. The authors strongly established factors that describe how such relationships vary according to different demographics and geographies in Indian culture. The work concluded that female autonomy is based on the sexual and marital relationships of women, and her post-marital relationship with two sets of kins. This determines their power, influence and social ranking in the country. This autonomy is further discussed in context of family planning, link of fertility with status, access to health services etc.

\section{Objectives of the Study}

To analyze the patterns of relationship between male and female gender in television advertisements in context of-

a. Decision-making

b. Division of labor

To decode main elements of gender relations in television advertisements with regard to-

a. Verbal elements

b. Non-verbal elements

To explore the current position of women in Indian households

To relate the position of women in gender relations as shown in television advertisements to their position that exists in the households

\section{Methodology}

Previous studies have approached this area of research by using quantitative scales to collect and analyze data on a small set of concrete variables with a little emphasis on critical analysis. But analyzing various factors of Gender Relations demands an in-depth observation and descriptive analysis of the characters and environment shown in television advertisements. That is, the quantitative approach is inadequate in analyzing the non-verbal elements in advertisements like colors, dresses, gestures, camera shots, facial expressions etc. Keeping this requirement in mind, pragmatic approach was adopted which provides the combination of quantitative as well as qualitative methods of data collection and analysis. For this, the method of content analysis was used. Sampling Unit of Analysis was Consumer Television Advertisements in Hindi and Coding Unit of Analysis was central female adult character visually portrayed in the advertisement. Children Ads or Ads containing animation or cartoons were excluded from the sample. First 500 TV advertisements were non-repetitively selected for the recorded prime-time content of Hindi entertainment channels Star Plus, Colors and Zee TV for a period of 12 months (July 2013-June 2014). These were the most viewed three channels) as per the report of (TAM) Television Audience Measurement [25]. The sample contained 550 such central characters who were further analyzed with reference to their opposite male characters on the basis of eight codes- Setting, Product Association, Decision-making, Help, Advice, Eye contact, Verbal Interaction, Physical Intimacy. For analyzing the position of women in the mindset of the society, a 
survey was conducted from 500 respondents of Delhi. A close-ended questionnaire was used as research instrument wherein first segment listed 27 tasks and 18 decisions related to domestic and outdoor life of a household to see who amongst the male and female dominates the relationship. The second section contained 37 attitudinal statements on various aspects of a woman's life. The sample of respondents included 250 males and females each.

\section{Data Analysis}

The analysis of advertisements on seven parameters revealed some important aspects about the way women are shown in relation to their associated male characters in the advertisements. The analysis for each code has been presented in the form of different figures and tables. Figure 1 displays the kind of product female central characters are shown as advertising in television advertisements [26]. The category of Beauty and Health products $(31.30 \%)$ were endorsed by maximum number of characters.

This includes cosmetics used to enhance beauty, looks and health, including medicines as well. It is followed closely by the category of Food products $(27.30 \%)$ which includes eating and drinking- related products. A close competition can be seen between the categories of Household products (12.90\%) and that of Recreation products $(12.20 \%)$. While the former includes appliances and cleaning products used for home management, the later refers to the products used for sports, music and other activities of passing time. It includes the products like laptops, mobile phones as well. Out of the remaining five categories, $6.7 \%$ products were related to finance, banking and insurance followed by $4.50 \%$ motor and car insurance products. While the products like Footwear and Clothes were only $1.80 \%$, no character endorsed any product related to Restaurants and Retail Outlets ( $0 \%)$. This category refers to the places used for selling of products to the public and includes eating places as well.

Figure 2 displays data about the location in which the central characters appeared. It reflects that

the most frequent settings for presenting women is home as more than half $(55.10 \%)$ of the characters have been shown in it. This includes domestic premises where the character is either alone or with husband/children. While $1 / 3$ of the characters appeared in environment away from home, the advertisers presented only $10.70 \%$ characters at their workplace. That is, the characters are least seen in occupational environment or location. $0.40 \%$ characters appeared in such environment that were either not identifiable or could not be included in any of these three categories. Table 1 presents the data

\section{Product Type}

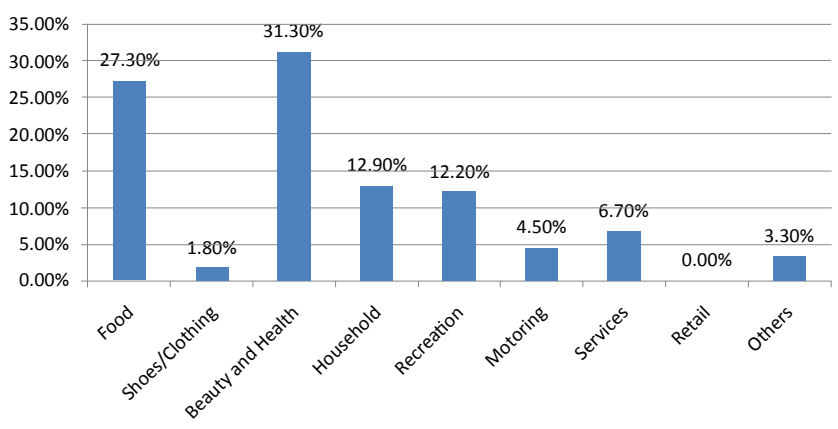

Figure 1: Kind of product advertised by the character.

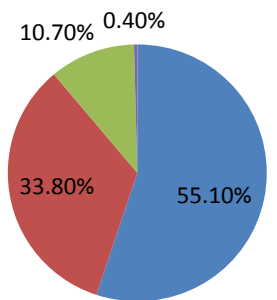

Home

Figure 2: Setting in which the character appears.

\begin{tabular}{|l|c|c|}
\hline Decision-making & Frequency & Percentage \\
\hline Decision-maker & 76 & 13.8 \\
\hline Follower & 138 & 25.1 \\
\hline NA & 336 & 61.1 \\
\hline Total & 550 & 100.0 \\
\hline
\end{tabular}

Table 1: Portrayal in situations of Decision-making with the associated male characters.

\begin{tabular}{|l|c|c|}
\hline Help & Frequency & Percentage \\
\hline Provider of Help & 38 & 6.9 \\
\hline Receiver of Help & 97 & 17.6 \\
\hline NA & 415 & 75.5 \\
\hline Total & 550 & 100.0 \\
\hline
\end{tabular}

Table 2: Portrayal in situations of Help with the associated male characters.

regarding the activity of taking important conclusions or resolutions by both the central character and the male associated with her in the advertisements. It can be seen that $1 / 4$ of the characters are shown as following the decisions (25.1\%) taken by their respective associated male characters whereas only $13.8 \%$ are shown as leading him in deciding for various things. A similar distribution of data can be seen in Table 2 in context of help between both the sexes. $17.6 \%$ of characters are shown as receiving services or resources from the males to make something happen followed by $6.9 \%$ characters as providing help to males. Thus, it can be concluded from the above data that male characters seem to dominate the central female characters in a significant number of situations where decisions are taken and help is seeked among both of them.

The trend in case of Advice seems to differ a bit in context of gender relations as out of 131 advertisements, both sexes are shown equal (48\% and 52\%) participants in giving and receiving help.

In case of advice, Table 3 reflects a close distribution between the number of central characters receiving advice from their associated male characters ( 68 characters) and those who act as advisors to the males in the advertisements ( 63 characters). Thus, a little more number of central characters are shown as receiving recommendations from or being guided by their associated male characters than the ones shown as advising.

In an attempt to analyze the interactive situations between both of them, eye contact of the character with the associated male in the advertisements was analyzed. Such aspects suggest the real life situations where two persons interact in a way as either one dominates the other or both are equal in participating in it. Table 4 reveals that $32 \%$ characters are shown as looking up to the associated male or away from him. This means that more than $1 / 3$ characters are presented as

looking up to males as authority over them or withdrawing from the interaction, thus placing her at a status lower than him. While $24 \%$ characters were presented as equally participating in the interaction 


\begin{tabular}{|l|c|c|}
\hline Advice & Frequency & Percentage \\
\hline Advisor & 63 & 11.5 \\
\hline Advised & 68 & 12.4 \\
\hline NA & 419 & 76.2 \\
\hline Total & 550 & 100.0 \\
\hline
\end{tabular}

Table 3: Portrayal in situations of Advice with the associated male characters.

\begin{tabular}{|l|c|c|}
\hline Eye contact with Male & Frequency & Percentage \\
\hline Direct Eye Contact & 132 & 24.0 \\
\hline Look Down & 4 & .7 \\
\hline Look up or Away & 176 & 32.0 \\
\hline No such interaction shown & 238 & 43.3 \\
\hline Total & 550 & 100.0 \\
\hline
\end{tabular}

Table 4: Eye Contact while interaction with Male Character.

\begin{tabular}{|l|c|c|}
\hline Verbal Interaction & Frequency & Percentage \\
\hline Dominates the interaction & 72 & 13.1 \\
\hline Gives up during interaction & 101 & 18.4 \\
\hline Equal Participation & 52 & 9.5 \\
\hline No interaction shown & 325 & 59.1 \\
\hline Total & 550 & 100.0 \\
\hline
\end{tabular}

Table 5: Verbal Interaction of Character with the Opposite Male.

through listening, responding and looking directly into the eyes of the associated male in the advertisements. However, hardly 4 out of 550 characters were presented as dominating the male during interaction by looking down at him as an authority. If 238 characters that fall in the category of the situation where no such interaction was shown are excluded from the total number of 550 characters, it can be said that $57 \%$ of the characters shown in interactive situations were placed in a position subordinate to that of the opposite male.

A similar analysis was carried out in context of the dialogues exchanged between the character and her associated male character. Data displayed in Table 5 reveals the analysis of Verbal Interaction of the character.

Out of the total 225 characters shown involved in interpersonal communication with the associated male characters, $45 \%$ are portrayed as accepting males' views without arguing or discussing on it. While $32 \%$ are portrayed as dominating the interaction, $23 \%$ characters have participated in equal manner. After excluding the 325 situations where no such interaction was shown, a total of 225 situations can be said to contain such interaction. Out of this, $44.8 \%$ characters (101/225) are shown as giving up during interaction. This means that approximately $45 \%$ of the characters are shown as listening to their opposite male characters and accepting his views without giving any logic for further discussion. While $23 \%$ characters were shown as equally participating in it, only $32 \%$ characters were presented as putting their point forward in a confident way by making the opposite male listen to their voice.

Figure 3 shows the data regarding the level of intimacy that the central character shared with the opposite male characters in terms of physical distance maintained while talking to them. The space can be divided into six zones as per the proxemics branch of body language.

The data reveal that $23.10 \%$ characters were presented as sharing Personal Zone with the males which means distance of 18-48 inches. It is followed by $15.50 \%$ characters presented in Social Zone (4$12 \mathrm{ft}$ ) in the advertisements. $11.10 \%$ and $9.80 \%$ can be seen to have been sharing Close Intimate Zone (less than 6 inches) and Intimate Zone (6-18 inches). Combined together, these two categories of high

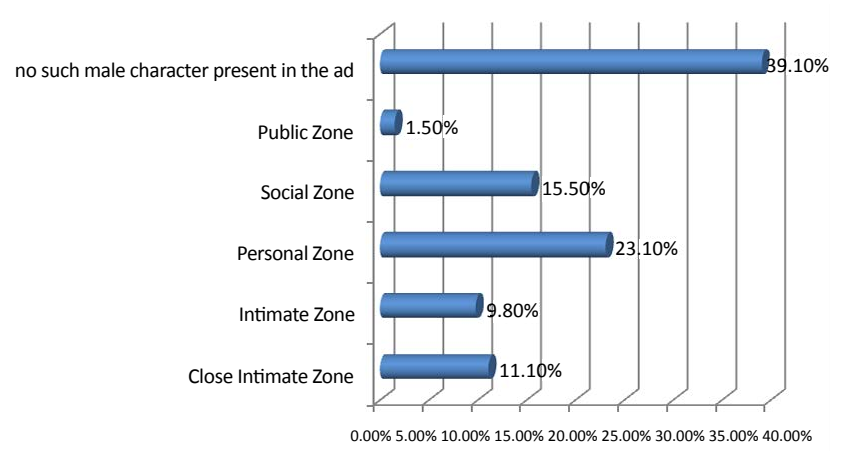

Figure 3: Physical Intimacy with the associated Male Character.

intimacy form $20 \%$ of the total characters. If $39.1 \%$ situations with no male character are excluded from the data, the categories of intimacy and close intimacy (20\%) form $1 / 3$ of the remaining $60 \%$ situations featuring male characters along with the central females. The zone that gets least percentage of characters is the Public Zone (1.50\%) which is defined as a distance of more than 4 feet from the opposite male characters. These situations were observed in the context of males shown as having no blood relation with the females. Thus, it can be said from the above analysis that $1 / 3$ characters are shown at physically intimate distance from the male characters by the advertisers.

\section{Descriptive analysis}

Apart from the quantitative data, analysis of various verbal and non-verbal elements in the advertisement reveal some important things about the way gender relations are shown in the advertisements. Following are few of those advertisements-

The advertisements clearly portray an imbalance between the amount of work done by men and that done by women. While females are shown working both inside the household and outside as well, it seems that the males have been kept by the advertisers for enjoying their limited professional life. The first advertisement in this context is that of Crocin Advance tablets. The ad opens with the shot of rising sun followed by fast forwarded shots of bread toasts, egg fry, lunch boxes, uniform, newspaper getting slide from the door- which clearly sets up the scene of a busy morning in a family where husband and children are shown getting ready for their office/schools. But the woman is shown assisting all of them in their tasks. Right from the tying of laces of children's shoes to packing their lunch box, to responding to the call of husband for his hankies, socks etc., followed by tasting of spices in vegetables, preparing the project models - every bit of big and small work is being done by her. While the ad conforms to the traditionalist views of cooking done by women only, one can still ask for sharing of other tasks by them, as after all the household and children belongs to both the sexes (Figure 4). This kind of portrayal demarcates the household zone for women conveying indirectly that it is their responsibility to manage home and everything else. Commencing on this politics of space, Kamla Bhasin says if a woman can cook, so can a man, because a woman doesn't cook with her womb! (p. 5) [2]. Though the issue of sharing of work has been raised by brands like Ariel and

Lloyd through their campaigns of 'Load Sharing' and 'unisex Washing Machine', 99 percent of ads continue to show women doing more work and thus, overshadow these one or two ads when they are targeted to a patriarchal society like India. This belongingness of different things to men and women is only an aspect of the wider 

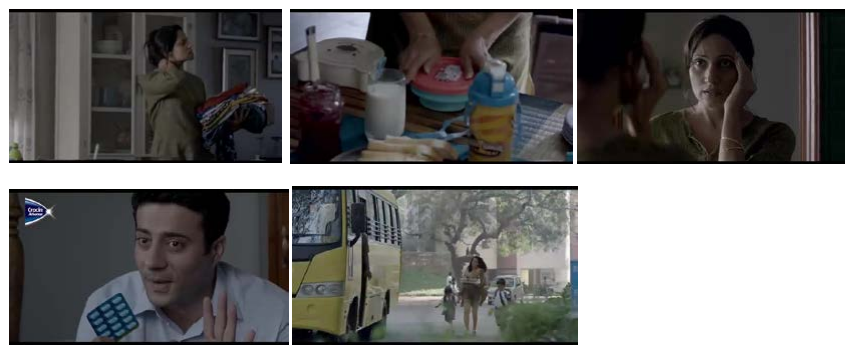

Figure 4: Snapshots of TV Advertisement for Crocin Advance.
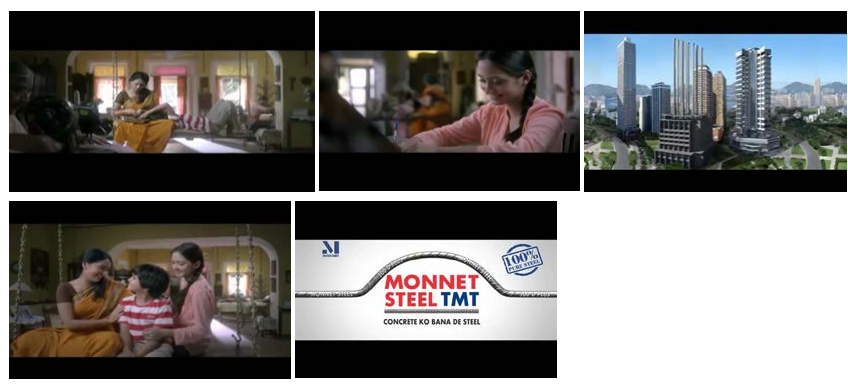

Figure 5: Snapshots of TV Advertisement of Monnet Steel.

distribution and control over resources - physical, financial, material between them. The one who does not have access and control over the resources becomes dependent for his/her mobility, consumption, enjoyment, socialization etc., on the other. In this context, it seems that the advertisements have left no stone unturned to make sure the women becomes dependent on men in her daily tasks outside the home, and thus, she is the 'second sex' in the words of Semoune De Beauvior- the one who is complimentary to and comes after the first (Males) [3]. The commercial of Monnet Steel begins with the opening long shot of a household with three women and a male child. The grandma is stitching clothes on a sewing machine while the mother is shown cutting vegetables and the daughter is studying. At the same time, the male child who is resting in the mother's lap on a jhoola tells his wish of making a home for his mother. Upon asking the name of that home by the sister, he mentions 'India'. At the same moment, the advertiser shows the photo of the product and talks about making a strong future of India with it. On one hand, the ad has conveyed that the place of females is that of performing household work and that of the male as the one who would build property in the $21^{\text {st }}$ Century India, the mother's dialogue that the boy has grown up symbolizes that the males ought to have control over money, property and other material resources in their hands in order to build a bright future of the country. In this way, the whole family- educated sister, experienced mother and the senior most members - grandmother would be dependent over him for their resources of daily living (Figure 5). Moreover, in the effort of the brand to make the consumers connect with it naturally, it features the happy expressions on the faces of all the three ladies when he is enjoying eating the vegetables as the three women are working - this symbolizes their acceptance of delegating the right to property in the hands of the male as an authority over them.

As Kamla Bhasin puts it - An analysis of the main institutions in society- the family, religion, law, political, educational and economic institutions, media, knowledge systems -demonstrates quite clearly that they are all patriarchal in nature, and are the pillars of a patriarchal structure. This well-knit and deep-rooted system makes patriarchy seem invincible; it also makes it seem natural (p. 21) [2]. Another form in which men are shown to be made authority over women is in approving the looks of women. While this aspect of gender relations is shown in the form of females getting ready thinking about getting appreciation, approval from or doing some magic on males, it gives men power over the mind and body of women. That is, the mere thought of attracting the male partners regulates the actions, gestures and other activities of women. How this factor operates in the relationship of a husband and wife can be seen in the advertisement of Venus soap featuring Vidya Balan. The whole ad is set in the premises when she is getting ready for her husband as he informs her on phone that he would be coming back from work in a while. As she smiles with a shyness on her face and moves to her bathtub, the voice over says it all- 'dil intezaar karta hai, sajta sanvartaa hai ...........chehre ko mili aisi rangat, mera aaina mujhse jalta hai'. During the last line of the background song, she looks into the mirror as her husband might look at her. The face expressions clearly revel that she was getting ready in the dress and apparels that her husband likes the most. Thus, her mind and body can be seen as being controlled by the thought whether her husband would be impressed or attracted by or like her the way she gets ready, while the husband is shown involved in his work at the office. In this manner, the male gets control over not only the earning and mobility aspect of the relationship, he has full control over her body as well (Figure 6).

The reason for this kind of social behavior by males and females can be tracked in the social learning and training of the kids in our society where they learn how to become 'women' from being a female and how to become 'men' from being a male. Thus, the assigning of different abilities, roles and characteristics to both the sexes defines their place, field of work and responsibilities when they grow up. This association of sexes with certain stereotype characteristics can be seen in the commercials like that of Saffola oats where a slim woman is shown following a diet pattern to control fat while her fatty colleague and husband are shown eating whatever they like without bothering about the fats/cholesterol. This points out to the typical characteristic of being figure conscious associated with the females by the society. This association is done with the men as well when actor Ranbir Kapoor is shown riding Hero Maestro with a girl sitting at his back. As the song says- "azaad hun main jaaun jahaan ...pataa na mera hai kahaan... jaisa bhi hun nahin main bura," he is shown highlighting the features of the scooty to the girl who is expecting a commitment for marriage from him. As both of them get off the vehicle, he is shown as making fun of the commitment and marriage thins, which is followed by his winking of the eye to the viewers saying- 'Boyz ki life aur maestro ki ride easy hai'. This points out to the freedom that the boys take in following a girl or roaming around with her as a show symbol without any commitment. This 'right to enjoy girls' is also emphasized at the end of the ad when he mentions the scooty as a 'boyy thing' Such association

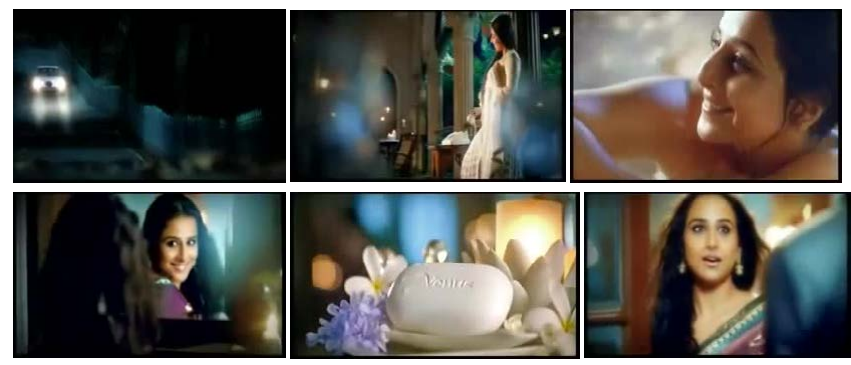

Figure 6: Snapshots of TV Advertisement for Venus 
of characteristics has a potential of teaching what should the society expects from woman, that further influences the way both the sexes are brought up by the families, especially their education, skills, behavior etc (Figure 7).

The more a society is patriarchal, the wider the difference in the attitude towards both the sexes is. The advertisement of HCLME tablets has been shot on the theme of the festival of Rakhi. The long shot of a royal palace-like home in Rajasthan is followed by the shots of home decoration, Rangoli, decorated thaali of Rakhi - all convey the traditional life style of that family. One traditionally-dressed woman along with a small girl opens up the said tablet and talks to her brother who, as the voice-over states, stays abroad. As the advertisement shows the way they both are talking to him, the voce-overs tells about the change that tablets assist in the interaction of those who stay at distance. But the visible difference is in the body language of the girlwhile the confident brother has been sent abroad, both females are shy in talking and traditional in lifestyle. This clearly reveals the difference in the conditioning and spending on education of male and female.

Another ad that reveals how the mindset of both the sexes are built up is that of Futura pressure cooker where a mother tells her daughter to learn cooking as she has to get settled in near future. After getting appreciation by her father, the daughter thanks her mother. The name of the brand symbolizes the future of a working girl as bright when she learns cooking for marriage. Such kind of bringing up in the families makes the society associate jobs and fields of work for both of them, which in turn restricts the abilities and potential of woman making her the weaker sex. The ad of TATA Tea shows this difference of fields associated with the expected masculine and feminine characteristics. It shows the confident and educated woman as a hospitality staff whereas an ill-mannered male is shown as a political leader, which clearly points out to the association of feminine trait of being good at hospitality and the masculine trait of being good at managing politics. This specialization of political knowledge followed by political participation is also visible in the commercial of Tata Tea's ad in which the husband comes home after voting and is advised to use helmet while driving by his wife. While the ad shows her educated and aware, she does not vote. This politics of restricting separate space for both the sexes can be observed in the ads of Nihar Shanti Amla that portrays Vidya Balan as teacher, and that of Windows 8 which shows women, despite of having knowledge to operate a Windows 8 laptop, as a housewife

\section{Position of women in the mindset of society}

The data of each of the three sections have been analyzed in the form of tables and graphs. First section measured the distribution of power between both the sexes in the household in terms of not only the number of decisions taken by each one of them, but also the kind of decisions taken by them.

\section{Decision-making in households}

A list of 18 daily-life decisions taken in a family was made and the respondents from 500 households were asked to choose the

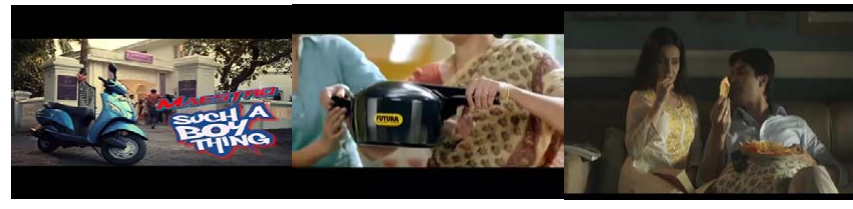

Figure 7: Snapshots of three advertisements (left to right)-Hero Maestro, Futura, Saffola Oats option about who takes that decision at their home. The list includes the decisions about small to major things related to both domestic and outside environment. It was found out that $39 \%$ of the decisions were taken by both men and women in the family, followed by $33 \%$ decisions by women and $28 \%$ by men. The results have been displayed in the form of four figures containing line graphs with the percentage of the decisions falling in each category. Figure 8 displays data about four decisions of listing food items, garments, footwear to be purchased along with deciding the place for family holiday. Data reflect that in $53 \%$ households, females decide the list of food items to be purchased for the family as compared to $18.4 \%$ households where males do such things. In more than half (50.40\%) of the households, women decide the garments to be purchased for all members of the family as compared to $14.6 \%$ males. Women seem to lead in deciding the purchase of footwear as well with $41.2 \%$ such households followed closely by $39.6 \%$ households where it is decided by both men and women followed by $19.20 \%$ cases where men are involved in it. However, the figure reflects a trend that $42.8 \%$ households are such wherein the decision regarding place and duration of family holiday is taken by both. It is followed by $31.6 \%$ cases where men decide this and $25.6 \%$ cases where women do. Figure 9 displays the data for five decisions regarding stationary, furniture, vehicles to be purchased for the family along with deciding the place of schooling for children and décor item for home like bedsheets, curtains, wall paintings, cushions etc. The data reveal high contrast in the percentage of women participating in decision for buying décor items and those involved in the purchase of vehicles like car, scooter, cycle etc. While $61.2 \%$ women can be seen involved in the former decision, only $8 \%$ have their say in deciding for vehicles. Similar contrast is visible in both categories in context of male participation that dips to $10.6 \%$ in the former and rises to $61.6 \%$ in the latter category.

However, participation in taking decision about the stationary items to be bought seems to be divided equally among men $(33.8 \%)$ and women $(33.8 \%)$. The pattern of decision making in rest of the two categories of furniture of home and schooling of children seem to be identical to each other in terms of their division between men, women and both. That is, there is equal participation by both in deciding the furniture (44.8\%) for home as well as about the school $(42.8 \%)$ in which the children would be admitted for their studies. Figure 10 contains data regarding five decisions to be taken in the households.

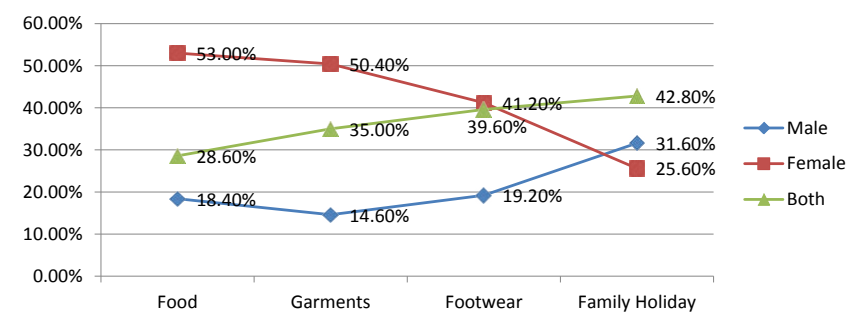

Figure 8: Patterns of Decision-making in Households (a).

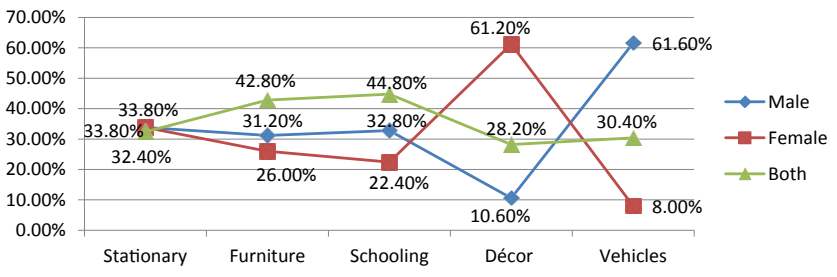

Figure 9: Patterns of Decision-making in households (b). 


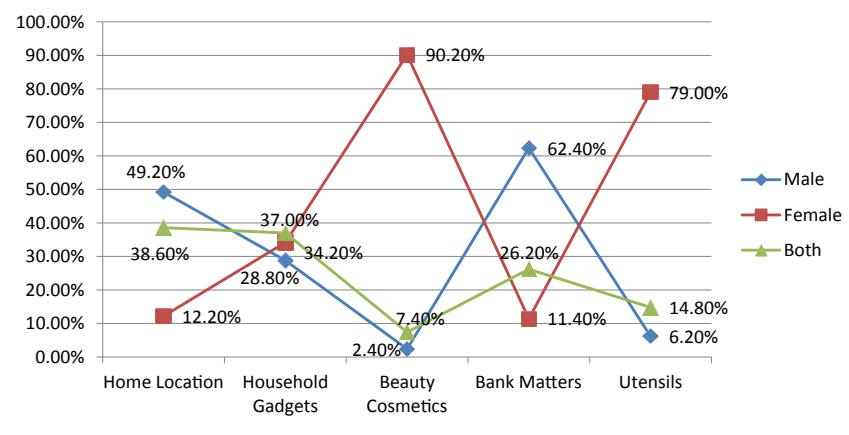

Figure 10: Patterns of Decision-making in households (c).

The decision for buying household gadgets like washing machine, mixer grinder, microwave, refrigerator, vacuum cleaner etc., involves participation of both male and female in $37 \%$ households followed by $34.20 \%$ households with participation of only women and $28.8 \%$ with that of only men. Amongst rest of the four categories, decisions about beauty cosmetics contains a high percentage (90.2\%) of women's participation and the lowest participation of men $(2.40 \%)$ followed by $7.40 \%$ households containing participation of both in it. Another category that has high percentage of women's participation is that of deciding about the utensils (79\%) to be bought for home and has a very low involvement of men from only $6.20 \%$ households. However, in the case of matters that require dealing with the bank, only $11.40 \%$ households are such where women decide these things. Whereas $62.40 \%$ households have the pattern where men hold command over such matters, followed by $26.20 \%$ households involving both men and women in the same. Further, when it comes to choosing the location of home, participation of women seems to dip (12.20\%) as compared to $49.20 \%$ households where men take this decision. This is followed by $38.60 \%$ cases where both the sexes participate in this decision. Thus, it can be said that the decision for three out of five fields have been solely occupied by either of the sexes. It is evident that the decision of cosmetics and utensils are taken majorly by women, whereas the decisions related to matters of bank and location of home are taken by men. The point of discussion is the abnormally low involvement of women in the financial matters and in choosing the location of home because these products are consumed equally by them as well. A similar point can be discussed about the percentage of men in the decisions of buying utensils for home. As displayed in Figure 11, the decision about buying recreation gadgets like laptops, mobile phones, television sets etc., is led by men in more than half of the households (50.40\%). While in $35.80 \%$ households, it is decided by both the sexes, participation of women seems to be low (13.80\%).

Further, this gap in the participation of men and women seem to increase while deciding about property and insurance matters. This decision involves discussion regarding selling or purchase of property and investment in insurance policy after considering and understanding the benefits being offered by different companies. In $65.40 \%$ households, this decision is taken by men whereas there are only $6.20 \%$ families where women lead in this decision. Also, this percentage of participation of women is the lowest of all the four categories of the decisions displayed in the figure. However, both the sexes can be seen involved in making the list of medicines to be purchased in $40.20 \%$ households. This is followed by males making this list in $38.60 \%$ families and women in $21.20 \%$ cases. A similar picture emerges if looked at the decision regarding visiting relatives' home. The distribution of data in this case reflects that $56.2 \%$ households are such where this is decided by both men and women while there are $26.60 \%$ and $17.20 \%$ families where the decision about visiting relatives' home is taken by women and men respectively. Thus, it can be said that the families seemed to have given the power of deciding about finance, property, technical gadgets and vehicles to men and that of cosmetics and domestic things to women. While some of the decisions have their equal involvement, the high contrast between their involvements in more than $60 \%$ of the decisions clearly shows one sex as the follower of the other.

\section{Division of Labor in households}

The next section in the survey was about the amount and kind of daily work done by both sexes in the families. Division of tasks between men and women reflects the nature of their relationship - who occupies what space inside and outside the home decides who is dominant amongst them and who is dependent on the other. A list of such tasks were given to 500 households and they had to tell who does what work in their family. The results of this section have been presented in form of the following graphs-

In Figure 12, the task of looking after the hospitality of guests is done by women in $69.80 \%$ households followed by $24 \%$ households where men perform this work and only $6.60 \%$ households are such where servants are given this responsibility The work of cleaning house is done by women in $65.40 \%$ households whereas only $12 \%$ households have men doing this followed by $33.40 \%$ cases where servants do this. The share of work done by women increases further when it comes to washing clothes where $74.80 \%$ households contain this trend as compared to $1.80 \%$ cases where men do this. It is followed by $23.40 \%$ households where it is done servants. The task of ironing clothes has participation of men to some level; i.e., $13.40 \%$ households are such where men iron clothes while $58.8 \%$ households feature women doing this. The task of physical exercise seems to be least divided and almost reverse of the other four tasks. In 78\% households, men do physical exercise as compared to $18.60 \%$ cases where women also do it. Figure 13 shows that the work of making breakfast is done by women in $83.60 \%$ households compared to $2.80 \%$ households where men participate actively in these. $13.60 \%$ households are such where breakfast is

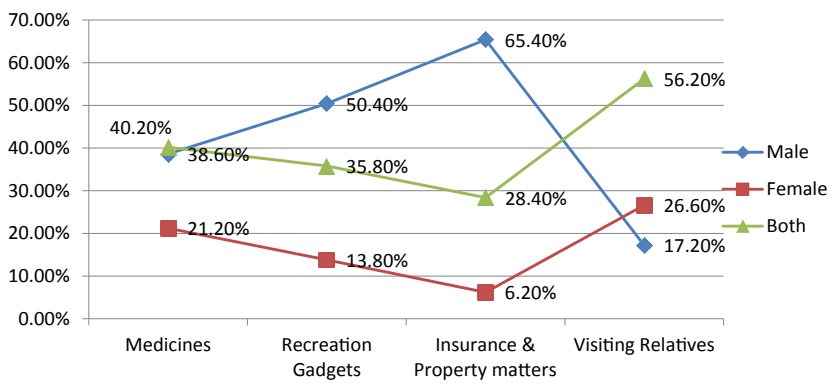

Figure 11: Patterns of Decision-making in households (d).

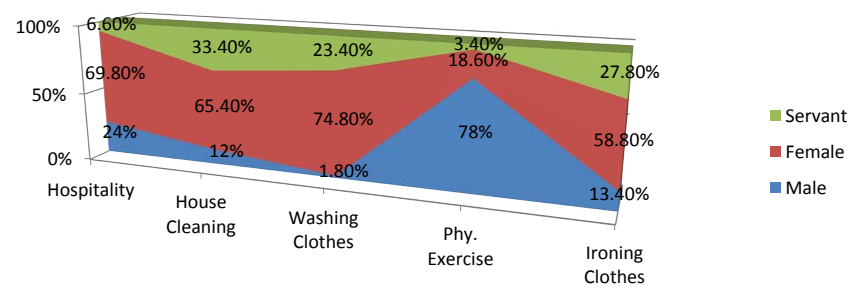

Figure 12: Division of Labor in households (a). 


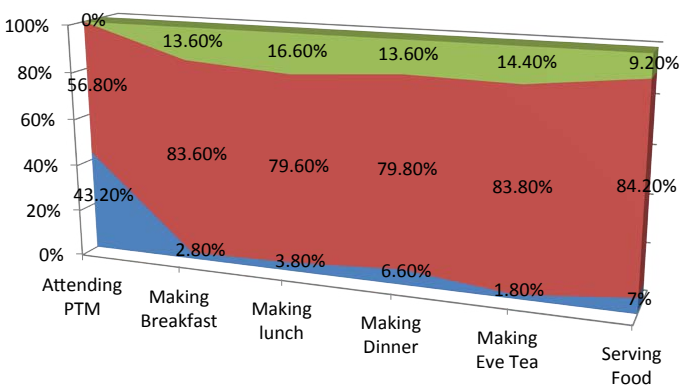

Figure 13: Division of Labor in households (b).

prepared by servants. The task of preparing lunch also seems to have been majorly occupied by women in $79.60 \%$ households whereas it is done by servants in $16.6 \%$ cases followed by men in $3.80 \%$ households. Making dinner for all family members in the evening is too done by women in $79.8 \%$ families as compared to $6.60 \%$ cases where men make it. Throughout these three tasks of cooking meals for the family, the work of cooking at morning seems to involve maximum participation of women while the participation of men seems to be increase a little bit from $2.80 \%$ in cooking during morning to $6.60 \%$ during dinner at night. Further, the data reflects that in $84.20 \%$ families, food is served by women to all the family members while in $7 \%$ cases, it is done by men. 9.20\% households are such where food is served by servants. As compared to the above four tasks, the work of making evening tea seems to belong solely to women as $83.80 \%$ households prefer it as being done by them whereas only $1.80 \%$ families are such where men prepare evening tea for the family. Sixth task about attending parents-teacher meeting at children's school is done by men in $6.80 \%$ households whereas $43.20 \%$ cases are such where women go to have this discussion (Figure 13).

It can be seen in Figure 10 that the task of maintaining gadgets at home is done by men in $71.60 \%$ households. It is done by women in $18.80 \%$ households followed by servants in $9.60 \%$ families. The task of reading newspaper of the day seems to be performed by men in $77.40 \%$ households as compared to $21.40 \%$ cases where women do it. The third task mentioned in the figure is about accompanying children to sports. The remaining two tasks of coordinating with helpers and helping children in homework contain comparatively more participation of women than men. That is, in $90 \%$ of households, the responsibility to supervise domestic tasks and home management like cleaning, washing, dusting, cooking, serving etc., is done by women whereas only $9 \%$ households are such where this is got done by men. The responsibility of helping children in their homework is taken by women in $79.26 \%$ households while there are $20 \%$ families where men perform this. It is followed by $4 \%$ cases where servants get it done (Figure 14).

The data displayed in Figure 11 seem to present a better picture than the previous sets of data in terms of participation of men. They can be seen performing the task of gardening at home in $33 \%(1 / 3)$ households, though more than half $(57.80 \%)$ households contain the trend where looking after and adding new plants to garden is done by women. It is followed by $9.20 \%$ families where this responsibility has been assigned to servants. Another task that involves participation of $33.60 \%$ men is related to purchasing of various things from marketplaces. There are $58.60 \%$ (more than half) such households where women do the task of shopping. This is followed by $7.80 \%$ cases where servants do this task. The responsibility of dusting is done by women in $9.80 \%$ households whereas only $6.20 \%$ families are such

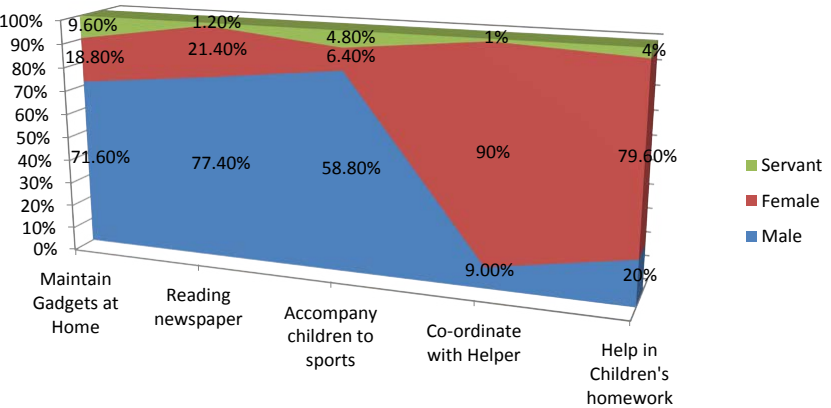

Figure 14: Division of Labor in households (c).

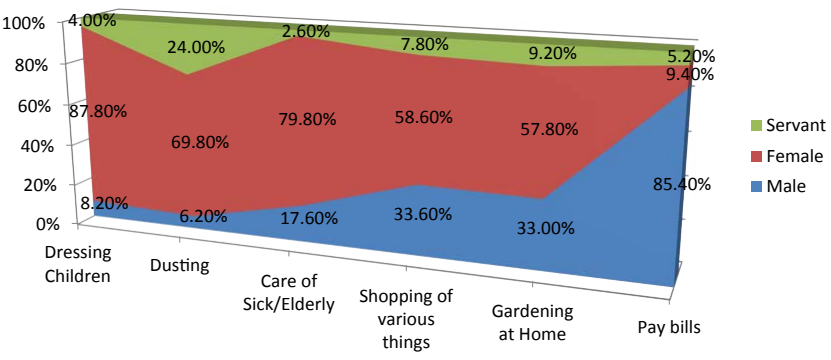

Figure 15: Division of Labor in households (d).

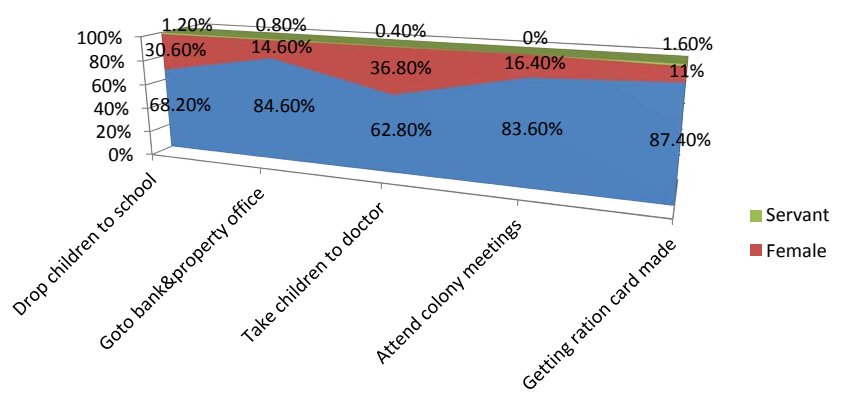

Figure 16: Division of Labor in households (e).

where men perform this work followed by $24 \%$ households where servants do it. The responsibility of dressing up children for going out to school or picnic or parties or sports has been given to women in $87.80 \%$ households whereas in $8.20 \%$ families, this is done by men followed by $4 \%$ cases where servants perform this. The task of taking care of sick or elderly members in family is looked after by women in $79.80 \%$ households as compared to $17.60 \%$ families where men perform this task. In less than 3\% (2.60\%) families, it is assigned to servants at home. The sixth task of paying bills for water, electricity etc. is done by men in $85.40 \%$ households while in $9.40 \%$ families, it is assigned to women (Figure 15).

Figure 12 displays the remaining set of six tasks that relate to the things to be done outside the home or domestic environment. The task of dropping children to school is done by men in $68.20 \%$ households as compared to $3.60 \%$ households where women do this. In $1.20 \%$ cases, this responsibility is assigned to the servant. Further, the data reflects that $84.60 \%$ families feature the trend where men deal with the matters of bank, insurance and property while there are $14.60 \%$ cases where women handle these. Hardly $1 \%(0.80 \%)$ households are such where it 


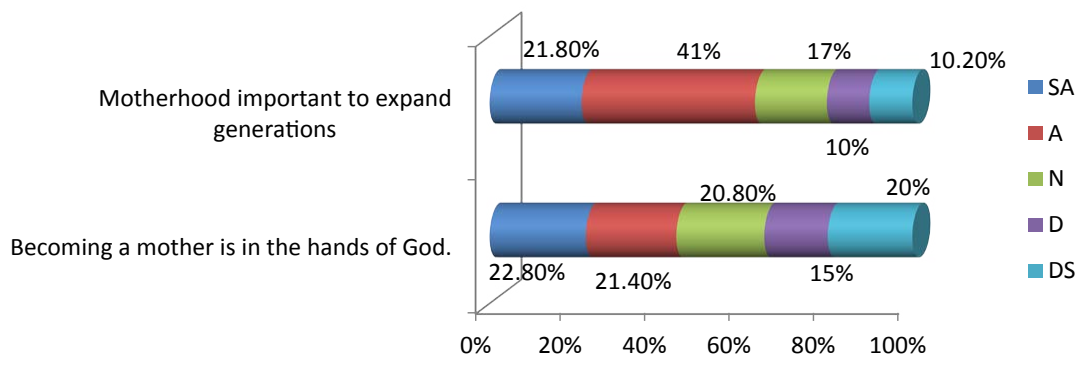

Figure 17: Response on statements regarding motherhood.

\begin{tabular}{|c|c|c|c|c|c|c|}
\hline S.No & Abbreviated Statement & SA & A & $\mathbf{N}$ & D & DS \\
\hline 1 & Motherhood important to expand generations & 21.8 & 41 & 17 & 10 & 10.2 \\
\hline 2 & Becoming a mother is in the hands of God. & 22.8 & 21.4 & 20.8 & 15 & 20 \\
\hline 3 & Don't prefer artificial birth control methods & 15.2 & 16.8 & 28.4 & 15.2 & 24.4 \\
\hline 4 & Wife's duty to fulfil her husband's physical desires. & 22.6 & 24.4 & 21.8 & 11.6 & 19.6 \\
\hline 5 & Right to have sex with wife & 16.2 & 12.8 & 19.6 & 30 & 21.4 \\
\hline
\end{tabular}

Table 6: Opinion about Control over Body of women.

is left to servants. In $62.80 \%$ households, men take children to doctor for treatment followed by $36.80 \%$ families in which women do this and only $0.40 \%$ where servants do the required tasks (Figure 16 ).

Fourth task of attending meetings held at the level of colonies is done by men in $83.60 \%$ households followed by $36.80 \%$ such households when women are involved in it. The last task that was asked about is about getting the ration card made. In $87.40 \%$ families, this is done by men followed by $11 \%$ households where women get it made and $1.60 \%$ cases where servants are assigned this responsibility. Thus, it can be concluded that the division of labor between men and women is that of 5:8. Moreover, a clear demarcation of space can be seen in the society where domestic front is reserved for females and outdoor for males. While the amount of work done by the women in an average household breaks the perception that women are physically weak, it also conveys the politics in the families where one sex does most of the work for all members but the opportunity of representing it goes to the other one. The association of males with relaxation, financial dealing, representation, access to the modes of increasing knowledge and getting socially connected reflects the patriarchal mindset of the society where females are expected to spend their whole life and energy in serving family members and guests.

Both the sections present a picture where men have control over mobility, leisure, finance, property, relations with community and women depend upon them for getting ration cards, bank accounts, paying bills, dropping and picking up children for various activities.

\section{Attitude towards Women}

The third section of the questionnaire contains 25 attitudinal statements to measure the mindset of the society towards women. These are related to various aspects of a woman's life and stated in a manner that conveys traditional image of a women in Indian society. Each statement was a 5-point Likert item and asked the respondents to choose their response from 5 to 1, where (5) means Strongly Agree and (1) means Strongly Disagree. Out of the 26 statements, 5 statements were about control over women's body, 10 statements asked about mobility of the woman and 10 statements were related to bringing up of male and female in the society. Keeping in mind the nature of the scale, percentage of individual responses have been calculated. For easier comprehension of data, different statements have been analyzed under the categories of their respective variables. Since the scale was a disguised one, i.e., the statements are asked in a hidden way, the scale used more than one statement on one aspect and the conflicts, if any, are presented and analyzed in the form of tables and figures.

\section{Opinion about Control over Body of Women}

Table 6 contains the percentage of responses received on the statements related to body of women. A clear concentration of responses can be seen under the category of agreement (41\%) in the first statement that asked about the expansion of generation being a factor for motherhood. Further, $21.8 \%$ respondents strongly gave their consent to it.

While $17 \%$ could not make up their mind on this aspect, $10 \%$ respondents marked a clear disbelief towards it. An almost equal percentage of participants can be seen who expressed their disbelief strongly $(10.2 \%)$. If the scores are looked at on either side of the neutral option, there is a clear inclination of majority of respondents (61.8\%) towards agreeing to the statement that this decision depends on the consideration of expanding generation in a family. But another statement about motherhood received a response which is totally different from the first one. Figure 13 displays scores received on both the statements-The respondents were asked about becoming mother depending on the will of god. The responses got distributed almost equally in four out of the five levels on the scale with a minute difference of hardly $1 \%$. That is, $22.8 \%$ conveyed a strong agreement with the statement while $20 \%$ opposed it strongly. Thus, it can be said that more than $40 \%$ respondents hold drastically different point of view from each other in this context. While $15 \%$ respondents disagreed with it, $20 \%$ respondents disagreed more intensely with the statement. $20.8 \%$ respondents neither agreed nor disagreed to the aspect in question. By looking at the scores on this statement in totality, more than $40 \%$ respondents seem to be inclined towards agreement on this aspect. Thus, opinion on both the statements conveys the mindset of the majority that the will of a woman to become mother either depends on the considerations of family or considered as a will of God and not as her own right to decide for it (Figure 17). 
Citation: Bhatia C, Singh MD (2016) The Sun and Satellite: A Study of Gender Relations in Television Advertisements and its Relationship to the Position of Women in Indian Households. J Mass Communicat Journalism 6: 324. doi: 10.4172/2165-7912.1000324

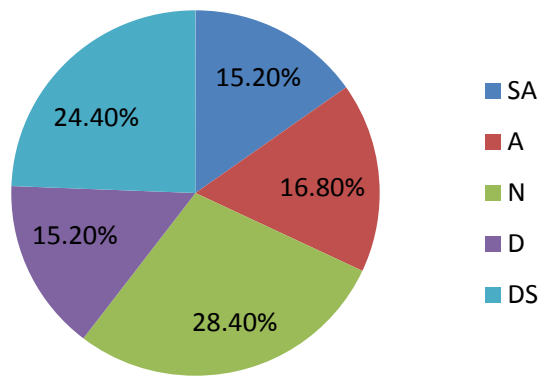

Figure 18: Response on statements regarding artificial birth control methods.

Right to have sex with wife
Wife's duty to fulfil her...

Figure19: Response on statements regarding sex with partner

\begin{tabular}{|c|c|c|c|c|c|c|}
\hline S. No & Abbreviated Statement & SA & $\mathbf{A}$ & $\mathrm{N}$ & D & DS \\
\hline 1 & First mother, then father should look after children & 20.2 & 16.7 & 13.6 & 34.6 & 14.9 \\
\hline 2 & Girls can help mothers in household work. & 26.4 & 52.1 & 14.4 & 3.4 & 3.7 \\
\hline 3 & Mother responsible for looking after children. & 31.2 & 23 & 15.6 & 15.6 & 14.6 \\
\hline 4 & Mother to take care of children more than career & 24 & 31.8 & 12.4 & 11.6 & 20.2 \\
\hline 5 & A wife to hand over salary to husband. & 10.2 & 37.1 & 13 & 43.8 & 4.1 \\
\hline 6 & Women not to go in public discussions and events. & 10.6 & 16.1 & 17.2 & 35.4 & 20.7 \\
\hline 7 & Women don't need separate bank account & 10.6 & 15.6 & 14.6 & 31.4 & 27.8 \\
\hline 8 & Wife to take up job that is acceptable to family. & 26.6 & 34.4 & 17.2 & 12.8 & 10.2 \\
\hline 9 & Women to take that job as suitable to the family & 20.4 & 42.2 & 14.4 & 20.6 & 2.4 \\
\hline 10 & Late timing jobs not good for girls & 28.2 & 20.4 & 17 & 13 & 21.4 \\
\hline
\end{tabular}

Table 7: Opinion about Mobility of women.

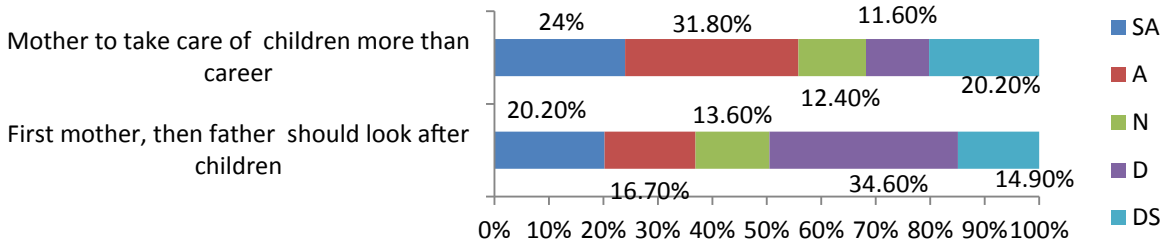

Figure 20: Opinion regarding responsibility of children.

On the statement of not using artificial birth control methods for women (Figure 18), almost $1 / 4^{\text {th }}$ of the respondents strongly feel disagreed to it (24.4\%). Thus, by observing the percentage of respondents who clearly expressed their opinion in favor or against the statement, the percentage of $24.4 \%$ that falls under the level of strong disagreement hold more weight over the others. While $15.2 \%$ hold a slight disagreement to this aspect, a slightly more percentage of respondents hold slight agreement (16.8\%) with it. While $28.4 \%$ did not have a clear mind about this, $15.2 \%$ respondents stand in strong agreement with the statement. Further, the whole side of disagreement on the statement shows inclination of almost $40 \%$ respondents. Therefore, it can be concluded that the respondents do not feel any problem in using artificial birth control methods like pills etc., for women's body. As far as the act of sex between the partners is concerned, there is a clear contrast in the opinion received on both the statements related to it. Figure 19 displays the distribution of responses received on both the statements-When asked about the partner having right over his wife to have sex, more than $20 \%$ respondents stand in a strong opposition to this along with an average level of slight disagreement by $30 \%$ respondents. While $12.8 \%$ respondents stand think slightly in favor of this statement, $16.2 \%$ reflected their strong favor for it. When the same respondents are asked about fulfilling of partner's desires as being the duty of wife, near to $1 / 4$ of respondents (24.4\%) slightly agreed to it with $22.6 \%$ standing in strong consent with the statement. Thus, if both the statements are looked at in totality, one can identify them as a mirror image of each other with $51.4 \%$ against it being a right of the husband and $47 \%$ in its favor when it has been asked in the tone of it being a wife's duty. This inconsistency between both the responses might be due to the respondents becoming conscious about their actual opinion when the statements are more direct like the former in this case. On the basis of this analysis, it can be concluded that the respondents hold mixed views about women to have right to decide for her body 
Citation: Bhatia C, Singh MD (2016) The Sun and Satellite: A Study of Gender Relations in Television Advertisements and its Relationship to the Position of Women in Indian Households. J Mass Communicat Journalism 6: 324. doi: 10.4172/2165-7912.1000324

wherein they favor adopting birth control measures but handover the control to her family or partner in cases of sex and motherhood.

\section{Opinion about Mobility of Women}

To assess the opinion of respondents about the aspect of mobility in the life of Indian women, ten statements were asked (Table 7).

These were based on major factors like children, household work, career and public events. All of these tasks not only consume a lot of time and energy of the family member dealing with it, but also reflects the space - public or domestic, the member remains into

First statement that the responsibility of children primarily belongs to mother than father received disagreement $(34.6 \%)$ from more than $1 / 3$ respondents (Figure 20 ). While $16.7 \%$ are in slight agreement with it, $20.2 \%$ respondents gave their strong consent for it. While $13.6 \%$ hold no opinion over it, $14.9 \%$ opposed the statement strongly which makes the opinion inclined towards disagreement on the scale. When the same thing is asked in the form of third statement, $31.2 \%$ respondents strongly favored the thinking that mother is responsible for looking after children. While $15.6 \%$ disagreed lightly, $14.6 \%$ respondents can be seen as strongly opposed to it. Further, 23\% respondents registered their agreement with this thinking which takes the score on the side of agreement to more than $53 \%$ on the scale. This reflects a strong inclination of the opinion towards the upper level of the scale - that is, towards agreement to associating the responsibilities of rearing and bringing up children to women. The contrast between the responses to both the statements can be understood as the father being helpful in looking after children, but their primary responsibility belongs essentially to women.

The third statement that asked about the girls helping mothers in household work received agreement from $52.1 \%$ respondents. That is, though the agreement is at the light level, but more than $1 / 2$ of the respondents stand in agreement with it. Further, 26.4\% respondents gave as stamp of strong agreement on it. While $14.4 \%$ respondents neither agreed nor disagreed to the statement, the score seems to fall towards the lower side of the scale with $3.4 \%$ respondents disagreeing to it and $3.7 \%$ reflecting their strong disagreement (Figure 21).

In this way, a strong agreement to this statement further reinforces

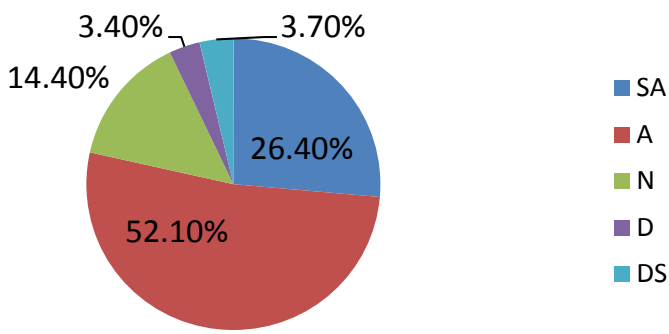

Figure 21: Girls can help mothers in household work.

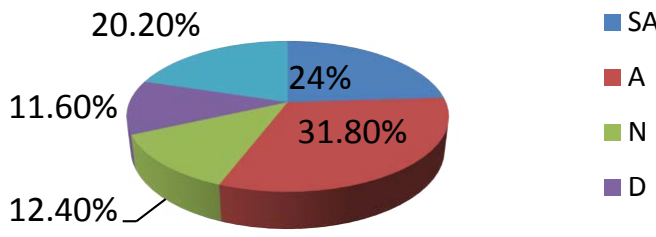

Figure 22: Mother to take care of children more than career.

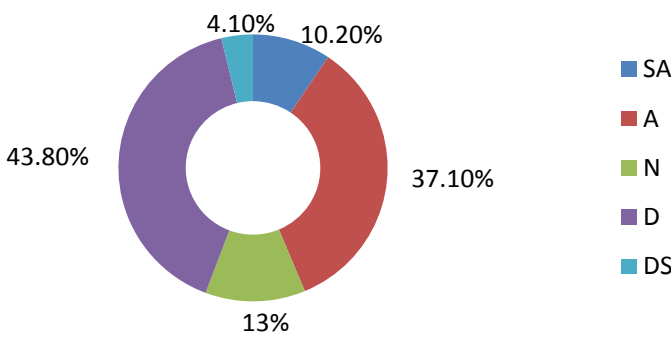

Figure 23: A wife to hand over salary to husband

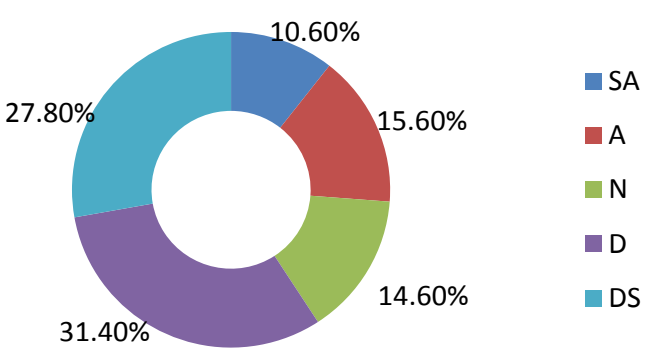

Figure 24: Women don't need separate bank account.

women's association with the tasks like cooking, washing clothes, cleaning, ironing, serving food etc., which would keep her stick within the boundaries of home. From these three responses, it seems that the society thinks that children and household work belong solely to women. When asked about the career of women being more important than the responsibility of children, $31.8 \%$ agreed to it. The percentages of response have been presented in the form of Figure 22 .

While $24 \%$ respondents give their strong consent to the statement, $20.2 \%$ opposed it strongly. $11.6 \%$ hold mild disagreement to this in their view whereas $12.4 \%$ do not take any side on the statement. The fifth statement asked about handing over of wife's salary to husband (Figure 23). The opinion seems to be divided on this aspect as $43.8 \%$ respondents feel slight disagreement to this along with $37.1 \%$ who mildly agree with it. While less than five percent respondents disagree strongly with it, $10.2 \%$ stand in strong favor of the statement which makes the score pattern on the scale tilted a little more towards the agreement side. $13 \%$ respondents neither agreed nor disagreed to it.

Another statement (Figure 24) asked about no need of a separate bank account for women wherein $31.4 \%$ respondents disagreed with it. Further, more than $1 / 4$ responses on level 1 of the scale reflect a strong disagreement $(27.8 \%)$ to it. $15.6 \%$ slightly agreed to the statement while $10.6 \%$ confirmed their opinion to it. Thus, an overview of the pattern of distribution of scores, the opinion seems to be inclined towards the lower side - that is, the side of disagreement. This means that the opinion, on the whole, favors a separate bank account for women. This points out to the thinking of the society about giving such economic independence to women that they can maintain a separate bank account. But this seems to be in contrast with the response on previous statements where respondents agreed to hand over of women's salary to husbands. This means that the society favors women's keeping of money separately but when it comes to expenditure, it believes the money should be handed over to men.

Upon asking about women not going to public discussion and events, $35.4 \%$ respondents don't agree with this. Further, $20.7 \%$ respondents registered their disagreement strongly. The agreement to 


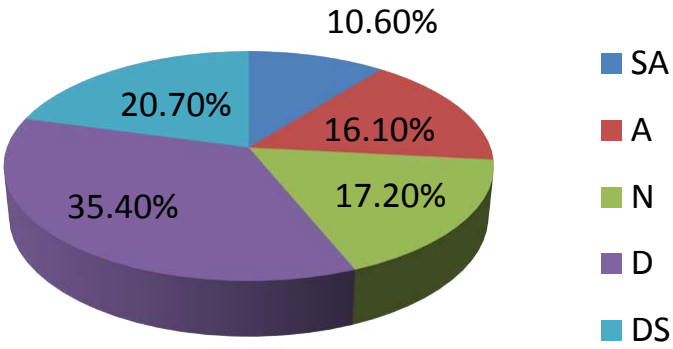

Figure 25: Women not to go in public discussions and events

$21.40 \%$

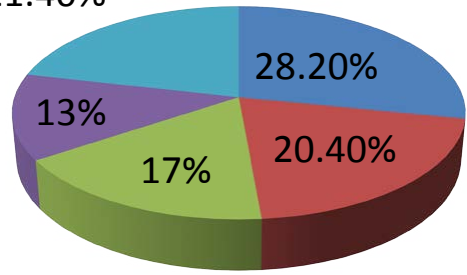

$\square$

$\mathrm{N}$

Figure 26: Opinion about late timing jobs for women.

statement seems to decrease as the level of the scale increases. $16.1 \%$ respondents registered their mild agreement to it while $10.6 \%$ agreed to it strongly. Thus, the scores can be overall seen as inclining towards disagreement. This means that the opinion is tilted towards women's freedom to go in public discussions and events. This alignment is visible in Figure 25.

As compared to the previous statements, the respondents seem to be more definite and clear-minded on the aspect of late timing jobs as not being good for women. This is visible in the pattern of response that fourth statement has received, as displayed in the Figure 26. A clear $28.2 \%$ strong agreement can be seen in the table along with $21.4 \%$ respondents reflecting a strong opposition to it. While $13 \%$ respondents disagree with it mildly, the percentage seems to increase with increase in the level as $17 \%$ chose the middle option of not inclining towards any side and $20.4 \%$ respondents choosing level 4 of slight agreement with it.

The first two statements are related to deciding the type of job women opt for. When asked about women opting for that job which is acceptable to the family, more than $1 / 3$ respondents $(34.4 \%)$ are in slight agreement to it. Further, $26.6 \%$ respondents registered themselves in strong agreement with it. While $12.8 \%$ respondents stand in mild disagreement to the statement, only $10.2 \%$ opposed to it strongly. In this way, more than $60 \%$ of the responses get concentrated at the level of 4 (Agree) and 5 (Strongly Agree) on the scale, i.e., towards agreement. When the same statement was asked differently in the form of second one, the overall distribution of respondents remained almost consistent among the five categories, the only change being the lesser number of respondents opposing it strongly $(2.4 \%)$ that shifted towards the level of slight disagreement. A considerable percentage (42.2\%) of respondents is in slight agreement with the job of women as being the one which is suitable to all members of family. While $20.4 \%$ respondents reflected their agreement strongly on this, $14.4 \%$ remain indecisive. Thus, both the statements majorly reflect the mindset of respondents to control women's right to decide for the kind

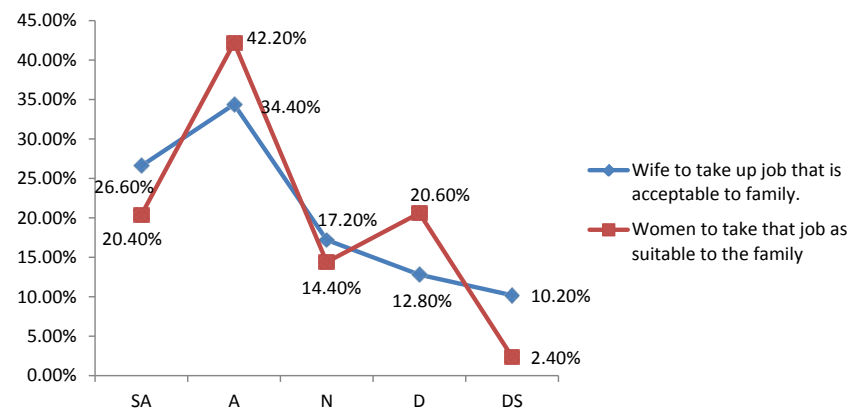

Figure 27: Opinion about deciding the type of occupation.

of job she wants to enter into. The presentation can be seen in the form of Figure 27.

From the above analysis, it can be concluded that the current society is in favor of giving economic independence to women in terms of keeping a separate bank account along with the space to go in public discussions and events. But on the other hand, it wants to keep the control over spending money in the hands of men. Also, the traditional role of women as wives and mothers are expected to remain intact in terms of children and household work as being their primary responsibility.

\section{Opinion about bringing up of Male and Female}

Respondents were asked ten statements about different characteristics that are thought to be associated with being male and female in the society (Table 8). These traits act as expectations or major factors for the treatment given to both the genders by institutions like family, school, media etc. Analysis of the responses has been displayed in the form of following figures-that asked the respondents about men suggesting women about their voting decision. Figure 28 displays the scores received on both the statements. When asked about men guiding for it, there is a conflict between the opinions as $25.2 \%$ respondents agreed a little to it while $27 \%$ slightly disagreed to the same. On the lowest and highest ends of the scale, 10.4\% stamped their strong opposition to this thinking whereas $18.4 \%$ stand strongly in favor of it, thus adding more weight to the scale on the side of agreement. 19\% respondents neither agreed nor disagreed with the same. When the same thing was asked in the form of actual discussion with father/husband before voting $31.6 \%$ respondents expressed their slight agreement to it. While $18.2 \%$ do not feel the same, $19.6 \%$ respondents disagreed more clearly. $11.4 \%$ respondents think in away strongly similar to the statement, thus making the total score on the side of agreement more than $40 \%$. Both the scores suggest the thinking of society that men are better at political knowledge and update than women and therefore, need to be consulted by the women for expert advice before they decide whom to vote for.

As seen in Table 8 , there are three statements regarding property and investment matters. Distribution of responses on all the three statements can be seen in Figure 29.

On the first statement that these are not meant for women, 35.8\% respondents chose to slightly disagree whereas $25 \%$ agreed slightly to it. At the extreme levels, $10 \%$ respondents expressed their strong agreement while $17.6 \%$ feel strong disagreement to it. When the same thing is asked in the form of men being better at it, a considerable percentage of respondents (38.9\%) agreed to it. This agreement got further emphasized with $20 \%$ respondents strongly expressing their 
Citation: Bhatia C, Singh MD (2016) The Sun and Satellite: A Study of Gender Relations in Television Advertisements and its Relationship to the Position of Women in Indian Households. J Mass Communicat Journalism 6: 324. doi: 10.4172/2165-7912.1000324

Page 14 of 17

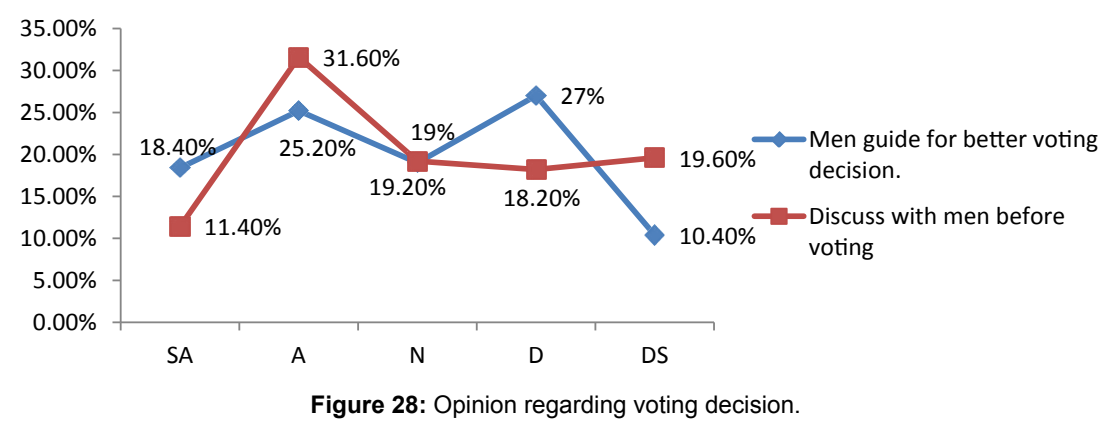

\begin{tabular}{|c|c|c|c|c|c|c|}
\hline S. No & Abbreviated Statement & SA & A & $\mathrm{N}$ & D & DS \\
\hline 1 & Property matters not for women & 10 & 25 & 11.6 & 35.8 & 17.6 \\
\hline 2 & Property matters handled better by men & 20 & 38.9 & 19.6 & 20.4 & 1.1 \\
\hline 3 & Men good at property and investment matters & 24.6 & 27.6 & 20.8 & 16.0 & 11 \\
\hline 4 & Teaching suitable to women. & 36 & 33.8 & 11.2 & 12.4 & 6.6 \\
\hline 5 & Defence and army jobs suitable for men. & 18.2 & 27.6 & 12.8 & 19.4 & 22 \\
\hline 6 & Women appropriate for hospitality. & 19.2 & 40.9 & 21.4 & 8.8 & 9.7 \\
\hline 7 & Discuss with men before voting & 11.4 & 31.6 & 19.2 & 18.2 & 19.6 \\
\hline 8 & Men guide for better voting decision. & 18.4 & 25.2 & 19 & 27 & 10.4 \\
\hline
\end{tabular}

Table 8: Opinion related to bringing up of male and female.

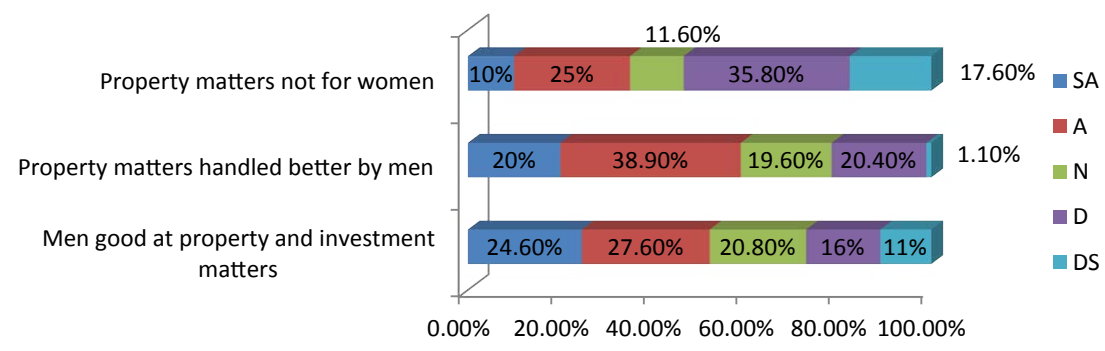

Figure 29: Opinion about stereotypes related to property matters.

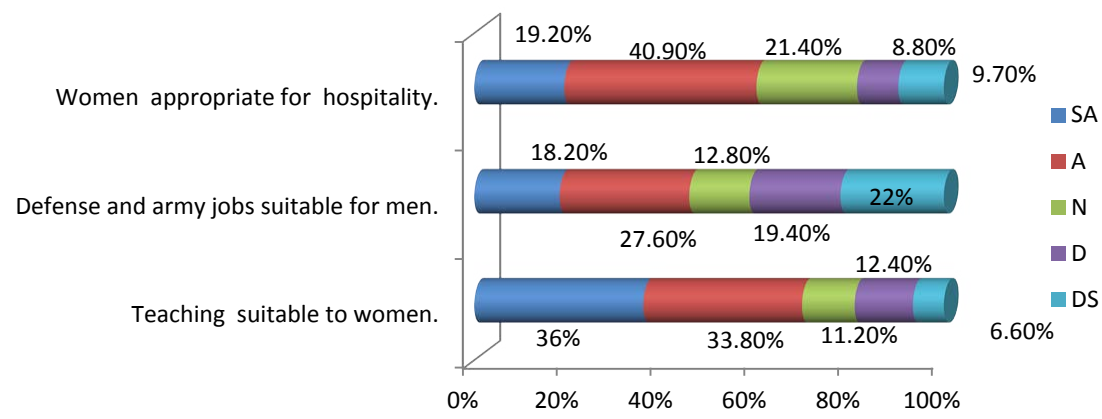

Figure 30: Opinion about stereotypes related to traits of women.

consent for the same. $20.4 \%$ felt lightly disagreed with it while less than $2 \%$ strongly disagreed (1.1\%) to it. Thus, a contrast is visible in the response pattern of both the statements. Further, when the statement was framed in the tone of men being good at it individually, the distribution of percentages seems to be quite similar to the previous one. $24.6 \%$ respondents strongly feel that men re good at handling such matters while $38.2 \%$ agree to it lightly. While $20.8 \%$ do not incline to the either side, $16 \%$ feel disagreement towards it. $11 \%$ respondents oppose the statement strongly. Since, being good at dealing with property implies having its good knowledge, we can say that the respondents seem to be moving towards agreement that the men are good at this knowledge and thus, good at dealing with it as well. Thus, on the basis of response to these three statements, it can be said that the society does not agree that property and investment matters are not meant for women, but at the same time, it thinks that they cannot do it as efficiently as men do because men are good at it. 
The seventh statement about defense jobs being suitable to men implies the association of characteristics like being rough-tough, good at physical fatigue and tasks of running, jumping, fighting along with features of bravery and courage in the personality. As can be seen in Figure 30, a clear concentration of the scores near level 4 and 5 is visible on the scale where $27.6 \%$ respondents agree slightly to it. On the lower side of the scale, $19.4 \%$ are in mild disagreement with the statement while $18.2 \%$ favored the thinking strongly, thus increasing the inclination of opinion towards agreement. This inclination seems to increase when the respondents are asked about the suitability of teaching job to women. more than $1 / 3$ respondents strongly favored the statement while $33.8 \%$ registered their lighter agreement on it. While $11.2 \%$ respondents chose the middle path by not choosing any side, $12.4 \%$ think with a mindset little different from the one asked in the statement. Only $6.6 \%$ respondents stand in strong disagreement to it. The inclination towards the agreement side crosses $50 \%$ when asked about hospitality as being appropriate for women with $40.9 \%$ respondents giving consent to it at a lighter note and 19.2\% backing it strongly.21.4\% remained neutral in their response, while $8.8 \%$ respondents touched the level 2 of disagreement. Less than $10 \%$ respondents disagreed strongly $(9.7 \%)$ to it. Thus, the opinion seems to be tilted towards agreement on all the three statements. Such kind of response implies that the society associates the same production and reproduction work in public space with women as they perform at home. That is, the tasks of nurturing, serving, healing, caring, bringing up and dealing with studies of children that women are expected to perform at home, the same is thought 'suitable' for her when she moves to public space as well. The word 'suitability' also implies the meaning of 'meant for'. Thus, it can be concluded that such tasks are meant to be associated with women and not men.

\section{Relationship between Gender Relations Shown on Television and Those Existing in the Society}

\section{Position of women in division of labor}

Both the advertisements and society seem to be practicing what Marx and Engels termed as the relationship of pleasure and work, of powerful and weak [6]. From the data collected by content analysis and survey, it can be seen that the division of labor between men and women is not only imbalanced, but also divides the spaces on the basis of gender. Women seem to perform more number of tasks than men. Moreover, the kind of tasks that each one of them takes up seems to be based on the societal ideas of what men and women should do and are capable of doing. At both the fronts, women have been assigned caring and nurturing works like washing, cleaning, cooking all three meals and serving them nursing of sick or elderly and that of leisure and financial dealing to men like reading newspaper, bank and insurance matters etc. Thus, the division of tasks divides the public or outside space (for men) and private or domestic space (for women). The former, that includes production and reproduction outside, is more recognized and considered valuable as it adds to economy and development as compared to the unpaid and invisible domestic production and reproduction. Such behavior leads to socialization based on different characteristics associated with both the genders. This seems to reinforce, in the words of Kamla Bhasin, the notion that men are born superior- with some special skills that justifies their power in the society [2].

\section{Position of women in decision-making}

Analysis of advertisements reveals that women are shown as weak in putting their points forward while interacting with men along with being follower of and dependent on them for important decisions taken inside and outside the household. This coincides with the situation in the society where the number and kind of decisions taken by women seems to follow the distinction of Public and Private space. Just as the ads relate women most frequently to beauty cosmetics and food products, similarly the survey reveals that the decisions taken by her are limited to beauty and health cosmetics along with domestic gadgets, utensils and décor. In contrast, men in our society have the power to decide for more financial, mobile, practical and outside dealings like vehicles, bank-insurance and property matters, recreation gadgets, home location, schooling of children etc., which is reflected in the advertisements when women characters depend over men for going out, for getting money, property and car etc. Thus, men have been placed in more valuable, powerful and leading positions in family and society and women have been placed in a situation where they have to bargain for their status at both the fronts. Apart from this control over financial and material resources, men seem to be having control over women's body as well. The advertisements show that the mind and body of women characters are controlled by male attention, attraction and approval of their looks, figure and style and this factor gets multiplied by presenting a large number of women characters in close intimacy with the opposite males. A quite similar picture gets reflected in the response of survey where men and family members seem to control women's body in terms of decision regarding her motherhood and will of having sex with the male partner. While this kind of portrayal by advertisements is seen by Naomi Wolf as politics of gender where women are kept busy in worrying about and fighting for male attention and men keep control over larger resources of the society, the views of respondents suggest that men along with family members hold power over women's body as well.

\section{Position of women with reference to their mobility}

Home seems to be the most favorite setting assigned to her by the advertisers with her primary role shown as that of a mother or wife. She is never presented as driving the family car or visiting banks and property offices or picking up and dropping children and other family members or partying with her colleagues or friends after office or exploring new travel destinations or attending colony and community meetings. Even the recreation gadgets like mobile, laptop, music system etc., occupy the third place in product association data. Being in the least contact with outside world, she is shown to be an unpaid worker at the disposal of her husband and children, round the clock, all her life- serving tea and dinner after her husband comes back from voting or office with his colleagues/friends. This expectation of acting like a superwoman - doing all the caring and nurturing work with a limited occupational role, i.e., serving as well as earning with a priority to the first one is approved by the society when the majority believes in training young girls in hospitality and skills of home management. Even when it comes to her financial independence, her salary is preferred to be handed over to her husband. That is, she is considered good for earning but has no independence about spending the same. Further, the kind and timings of job seem to be restricted by the husband and family members. Thus, both the advertisements and society seem to prefer women to remain limited to household and regular job with a dependence on partners in aspects of finance, occupation and roaming.

\section{Position of women in pattern of bringing up of male and female}

The traits observed in the form of interpersonal communication suggest that majority of women are shown as the one who accept the logic 
Citation: Bhatia C, Singh MD (2016) The Sun and Satellite: A Study of Gender Relations in Television Advertisements and its Relationship to the Position of Women in Indian Households. J Mass Communicat Journalism 6: 324. doi: 10.4172/2165-7912.1000324

of males during interaction, withdraw from the situations of discussion or argument and are less confident than men along with looking up to them as authority for recommendation or help in different situations. A similar picture emerges from the characteristics associated with men and women by the society. Significant agreement of respondents about women's looking up to males for political advice or business and property dealing, their associating of women with hospitality and teaching and that of males with defense and business suggest the belief of society that men are physically and mentally more powerful and skillful whereas women are meant for their delicacy, sensitivity, smiles, looks, presentation and skills of serving, caring, taking acre of students or children etc. Thus, a clear difference is visible regarding the treatment given to males and females. That is, a clear polarization based on sex is reflected where society associates female and male with two sets of qualities- body and mind, emotion and reason, subjective and objective, private and public, nature and culture- first set is considered as feminine and the other as masculine. This clearly supports the views of Geetha that mind is supposed to be superior to body, and culture an improvement on and superior to nature [27]. Those who are rational and objective are valued more highly than the ones who are subjective and emotional. Women are the bodies, almost like nature (they breed like animals), men are the minds, thinking, rational, acting beings who are superior, over and above nature and transforms it into culture by doing with it whatever they please to. Thus, the treatment of women by both the advertisers and society seem to be occupied with patriarchal ideology that governs the rule of men.

\section{Conclusion}

From the above discussion, it can be concluded that the television advertisements are positioning women at a status inferior and secondary to men which is similar to the one that exists in the mindset of society. This kind of relationship between men and women can be described in the words of Kamla Bhasin as Men in the families are like the Sun, they have a light of their own (own resources, are mobile, have the freedom to take decisions etc.) [2]. Women are like satellites without any light of their own. They shine only if and when the Sun's light touches them (pp.16). While a slight liberation can be seen in the attitude of Indian society in context of giving her a little freedom, the advertisements seem to be playing on the patriarchal mindset to earn profit by selling its products and services. Such kind of functioning of advertisements carries a risk of creating a pressure on women to confirm to such kind of behavior and expectations associated with it, thereby worsening their lives further.

\section{Operational Definitions}

\section{Setting-Location in which the central figure appeared}

2. Portrayal in context of Decision-making- What kind of personality does the character possess in comparison to the male character associated to her in the ad. Whether she leads him or follows him in Decision-making, i.e., making important conclusions or resolutions according to which work is done [9].

3. Portrayal in context of Help- What kind of personality does the character possess in comparison to the male character associated to her in the ad. Whether she leads him or follows him in offering Help, i.e. offering services or resources to make possible something [9].

4. Portrayal in context of Advice- What kind of personality does the character possess in comparison to the male character associated to her in the ad? Whether she leads him or follows him in Advice, i.e., guidance or recommendation to get something done [9].

5. Physical Intimacy with the associated male character - The level of intimacy that occurs between the central figure and the associated male character while engaged in contact .According to the proxemics- a branch of body language, given by Dr. Edward Hall, the space around a human being's body is his personal space. How much distance one keeps while talking to others conveys ones relationship with them. These intimacy zones are defined according to the physical distance that is maintained.

6. Eye Contact with the Opposite Male- Eye contact while interaction suggests the real-life situations where two persons interact. Such an expression between male and female tells about the status- dominance, subservience etc. of the characters [28].

7. Verbal Interaction With The Opposite Male - The kind of participation that the character does while interacting with the opposite male character.

\section{References}

1. Bina A (1996) A Field of One's Own. Gender and Rights in South Asia. Cambridge University Press.

2. Kamla B (2014) Understanding Gender. New Delhi: Kali for women.

3. Beauvoir S (1949) The Second Sex, New York: Vintage Press.

4. Foucault M (1982) The subject and power. In: Dreyfus H, Rabinow P Michel Foucault: Beyond Structuralism and Hermeneutics. University of Chicago Press pp:208-228.

5. Walby S (1990) Theorizing Patriarchy. Blackwell Publishers.

6. Karl M, Friedrich E (1932) The German Ideology. Progress Publishers

7. Kumar R (1993) The History of Doing: An Illustrated Account of Movements for Women's Rights and Feminism in India 1800-1990. Zubaan .

8. Nivedita M (2012) Seeing Like A Feminist. Zubaan.

9. Silverstein AJ, Silverstein R (1974) The Portrayal of Women in Television Advertising. Federal Communications Bar Journal 27: 71-93.

10. YadavJS, Abhilasha M (1987) Advertising and Social Responsibility. New Delhi: IIMC.

11. Roy A (1998) Selling Stereotypes: images of women in Indian television commercials. New Delhi: New concept Information Systems.

12. Chan K, Young SM (2002) Gender Portrayal in Hongkong and Korean Children's TV Commercials: A Cross-Cultural Comparison. Asian Journal of Communication 12:100-119.

13. Gunter B, Nassif A (2008) Gender Representation in Television Advertisements in Britain and Saudi Arabia. Sex Roles 58:752-760.

14. Ibroscheva E (2007) Caught between East and West? Portrayals of Gender in Bulgarian in Britain and Saudi Arabia. Sex Roles 58:752-760.

15. Goffman E (1979) Gender Advertisements. Cambridge: Howard University Press.

16. Lundstorm WJ, Sciglimpaglia D (1977) Sex Role Portrayals in Advertising Journal of Marketing 41:72-79.

17. Sciglimapglia D, Lundstorm WJ, Vanier DJ(1979) Women's Feminine Role Orientation and Their Attitudes toward sex role Portrayals in Advertising Current Issues and Research in Advertising 2:163-175.

18. Ali Haji M (2012) A critical analysis of women's representation in TV advertisements from a cultural studies perspective. International Journal of women's Research 1: 107-122.

19. Sangaris T, Pazarai EN (2008) Constructing Women's Image in TV Commercials-The Greek Case. Indian Journal of Gender Studies15:29-50. 
Citation: Bhatia C, Singh MD (2016) The Sun and Satellite: A Study of Gender Relations in Television Advertisements and its Relationship to the Position of Women in Indian Households. J Mass Communicat Journalism 6: 324. doi: 10.4172/2165-7912.1000324

Page 17 of 17

20. Bolzendahl Cl, Myers DJ (2004) Feminist Attitudes and Support for Gender Equality : Opinion change in Women and Men, 1974-1998. Social Forces 83: 759-789.

21. Furnham A, Mak T (1999) Sex-role stereotyping in television commercials:A review and comparision of fourteen studies done on five continents over 25 years. Sex Roles 41: 413-437.

22. Burns D (1995) Content Discontent: Towards A Fair Portrayal of Women in The Media. Santo Domingo, Dominican Republic: United Nations International Research and Training Institute for the Advancement of Women.
23. Dyson T, Moore M (2015) On Kinship structure, Female Autonomy, and Demographic behavior in India. Population and Development Review 9: 35-60.

24. Ceulemans M, Fauconnier G (1979) Mass Media: The Image, Role and Socia Conditions of Women A collection and analysis of research materials. UNESCO

25. Littlefield JE, Kirkpatrick CA (1970) Advertising: mass communication in marketing. Houghton Mifflin.

26. http://www.tellychakkar.com/tv/tv-news/tam-ratings-week-25-2013

27. Geetha V (2012) Gender. Bhatkal Books International.

28. Mueller B, Frith K (2003) Advertising and Societies: Global Issues. Peter Lang. 